DOI: http://dx.doi.org/10.21276/ap.2019.8.2.24
Annals of Phytomedicine: An International Journal
Pttp://Www.ukaazpublications.com/publications/index.php
Print ISSN : 2278-9839 Online ISSN : 2393-9885

Original article

\title{
Phytopharmacology of Ficus religiosa L. and its significance as nanoparticulate carrier
}

\author{
Navneet Mehan, A. Pandurangan, Prabhat Kumar Upadhyay*, Md Shamshir Alam, Shailendra Bhatt, Manish \\ Kumar*, Vipin Saini** and Rishabh \\ M M College of Pharmacy, Maharishi Markandeshwar (Deemed to be University), Mullana, Ambala, Haryana, India \\ *Institute of Pharmaceutical Research, GLA University, Mathura-281406, Uttar Pradesh, India \\ **M M University, Solan, Himachal Pradesh
}

Received October 5, 2019: Revised November 25, 2019: Accepted November 28, 2019: Published online December 30, 2019

\begin{abstract}
India is renowned for the development of health science based on Ayurveda, Unani, Siddha and Homeopathy. Ficus religiosa $\mathrm{L}$. is most popular species in these indigenous system of medicines. In F. religiosa, entire plant parts like flowers, leaf, fruit, root, bark, inner part of stem, seeds are used as bioactive ingredients. Recently, some pharmacological reports presented that medicinally active molecules which are important for future medication are obtained majorly from trees. These reports also established an explanation related to antidiabetic, anticancer, antiulcer, anticonvulsant, cell reinforcement, and wound recuperating properties of various parts of $F$. religiosa. Different parts of $F$. religiosa (roots, leaves, bark, fruit and seed) contains different types of active constituents which may help to treat various diseases. Extractions of F. religiosa in solvents (Ethanolic extraction, Water extraction, Methanolic extraction, etc.) are depend on the type of disease. Particulate frameworks like nanoparticles have been utilized as a physical way to deal with adjust and improve the pharmacokinetic and pharmacodynamics properties of different kinds of drug molecules. Nanoparticles are very small materials in the size range from 1 to $100 \mathrm{~nm}$. Distinctive kind of nanomaterials are being created by utilizing copper, zinc, titanium, magnesium, gold, alginate and silver. Nanoparticles of $F$. religiosa improve the medicinal property on different diseases like malignant growth, arthritis and so on. In this manner, the main intention behind writing this article is to present an advanced study on phytochemistry, pharmacological properites and nanotechnology of $F$. religiosa.
\end{abstract}

Key words: Ficus religiosa L., Ayurveda, nanoparticles, biomedicinally, methanolic extraction

\section{Introduction}

Moraceae is a family of some herbal plants (like Ficus religiosa, Ficus benghalensis, etc.) and this is also known as mulberry family or Fig family which contain near about 38 genera and over 1100 species. Peepal having botanical name is F. religiosa is the medicinal plant from Moraceae family. According to our traditional background, people revealed their reverence this tree. In India $F$. religiosa is planted near the religious or spiritual places which grows to the height of 5000 feet (Starr and Loope, 2003). Medicinal plants play an important role in the healthcare system in large proportion of the world's population (Barnes, 2002).The generation of Ficus contains about 800 species of trees, shrubs and epiphytes which are commonly found in tropical and subtropical region all over the globe (Loutfy et al., 2005).

Pharmacological examinations carried on the plant materials of $F$. religiosa give a reasonable support to its different conventional

Author for correspondence: Dr. Manish Kumar

Professor, M. M. College of Pharmacy, Maharishi Markandeshwar (Deemed to be University), Mullana, Ambala, Haryana, India

E-mail: manish_singh17@rediffmail.com

Tel.: $+91-7017 \overline{5} 48594$

Copyright (c) 2019 Ukaaz Publications. All rights reserved.

Email: ukaaz@yahoo.com; Website: www.ukaazpublications.com utilizations (Aiyegoro and Okoh, 2009). F. religiosa is one of the different plant generation as compare to other plants that developed with deciduous and enduring unattached trees, stranglers, climbers, little bushes and lithophytes (Ronsted et al., 2008). Aqueous and alcoholic extract of $F$. religiosa show the antibacterial action against some type of bacteria like Bacillus subtilis, Pseudomonas aeruginosa, E. coli and Salmonella typhi (Preethi et al., 2019). Restorative plants are normally gifted with precious bioactive mixes which structure the foundation of traditional drugs (Ramakrishnan and Hariprasad, 2012). In order to expand the wider use of medicine, at present new drugs show less or no symptoms of specific disease with an increasingly rapid and desired activity (Roy et al., 2009).

From a long time period, the herbal medicines are used for treating different type of diseases, as they have remedial properties because of the nearness of different complex compounds of different synthesis, which are found as auxiliary plant metabolites in at least one piece of these plants (Satyavati et al., 1976). Indian traditional medicine depends on different frameworks including Ayurveda, Siddha, Unani, and Homeopathy (Foye et al., 2008). Any piece of the plant may contain active parts like bark, leaves, roots, natural products, seeds, and so on. The beneficial medicinal impacts of plant materials normally result from the blends of auxiliary items present in the plant (Gordon and David, 2001). Bark of F. religiosa is used as antibacterial, antiviral 
antiprotozoal, etc. The leaves of this plant is used in skin sickness and anti-venom activity and manages the menstrual cycle ( Kalpana and Rishi , 2009; Chpora anc Chopra, 1958)

Ficus: It is a class of around 800 species and 2000 assortments, which are woody trees, shrubs and vines in the family Moraceae happening in most tropical and subtropical woodlands overall (Hamed, 2011). Ficus is one of the most adored bonsai. It is a phenomenal tree for beginners, as the most type of Ficus is quick growers, tolerant of most any soil and light conditions. About half portion of the species of Ficus are monoecious, and the rest are practically dioecious (Singh et al., 2011; Salem et al., 2013).

Numerous Ficus species are generally utilized in conventional medicine to treat different diseases. Sometimes they have been used as carminatives, vermicides, astringents, stomachic, anthelminthic and hypotensive drugs (Trivedi et al., 1969). Numerous species are developed for shade and decoration in nurseries. A few categories produce consumable Fig of differing acceptability. All species have latex-like material inside their vasculatures that give assurance and self-recuperating from physical ambushes (Srirsha et al., 2010). The Fig is an exceptionally supporting nourishment and utilized in modern items. Figs contain water, fats, high measures of amino acids, for example, leucine, lysine, valine, and arginine, and minerals (potassium, calcium, magnesium, sodium, phosphorus and Nutrients) (Joseph and Raj, 2010).

\section{Materials and Methods}

\subsection{Phytochemistry of $F$. religiosa}

Phytochemistry is the chemistry of $F$. religiosa, involve the chemical constituents of $F$. religiosa obtained from different parts of plant like are roots, bark, fruit, seed, etc., which are discussed below in Table 1:

Table 1: Chemical constituents in by different parts of $F$. religiosa plant

\begin{tabular}{|c|c|c|c|}
\hline S. No. & Plant part & Active constituents & References \\
\hline 1 & Roots & $\begin{array}{l}\text { Tannins, wax, saponin, leucoanthocyanins, delphinindin-3-O- } \alpha \text {-Lrhamnoside(II), } \\
\text { Pelargonidin-3-O- } \alpha \text {-Lrhamnoside, Leucocyanidine-3-O } \beta \text {-D-galactosyl-cellobioside(III), } \\
\text { Leucoanthocyanidin-20-tetratriaconten-2-one, pentatriacontan-5-one, } \\
6 \text { heptatria content-10-one, mesoanisosital }\end{array}$ & Asolakar et al., 1992 \\
\hline 2 & Bark & $\begin{array}{l}\text { Phenols, tannins, steroids, alkaloids, avonoids, } \beta \text {-sitosteryl-d-glucoside, vitamin K, } \\
\text { noctacosanol, methyl oleanolate, lanosterol, stigma sterol, lupen-3-one }\end{array}$ & Asolakar et al., 1992 \\
\hline 3 & Fruit & $\begin{array}{l}\text { Proteins (4.9\%), essential amino acids (isoleucine and phenylalanine), avonols } \\
\text { (kaempeferol, quercetine, myricetin), also contain good amount of total phenolic contents, } \\
\text { total avonoids, percent inhibition of linoleic acid , asgaragine, tyrosine, undecane, tridecane, } \\
\text { tetradecane, (e)- } \beta \text {-ocimene, } \alpha \text {-thujene, } \alpha \text {-pinene, } \beta \text {-pinene, } \alpha \text {-terpinene, limonene, } \\
\text { dendrolasine, } \alpha \text {-ylangene, } \alpha \text {-copaene, } \beta \text { bourbonene, } \beta \text {-caryophyllene, } \alpha \text {-trans bergamotene, } \\
\text { aromadendrene, } \alpha \text {-humulene, alloaromadendrene, germacrene, } \delta \text {-cadinene, } \gamma \text { cadinene. }\end{array}$ & Oliver and Bever, 1980 \\
\hline 4 & Seeds & $\begin{array}{l}\text { Phytosteroline, } \beta \text {-sitosterol and its glycoside, albuminoids, carbohydrates, fatty matter, } \\
\text { colouring matter, caoutchoue } 0.7-1.5 \%\end{array}$ & Bushra and Farooq, 2008 \\
\hline 5 & Leaves & $\begin{array}{l}\text { Campestrol, stigma sterol, isofucosterol, } \alpha \text {-amyrin, lupeol, tannic acid, arginine, serine, } \\
\text { aspartic acid, glycine, threonine, alanine, proline, tryptophan, tyrosine, methionine, } \\
\text { valine, isoleucine, leucine, n-nonacosane, n-hentricontanen, hexa-cosanol }\end{array}$ & $\begin{array}{l}\text { Panda, 1976, } \\
\text { Verma and Bhatia, } 1986 \\
\text { Behari et al., } 1984\end{array}$ \\
\hline
\end{tabular}

F. religiosa discharges oxygen constantly which makes it different from other plants. The majority of the plants take-up carbon dioxide $\left(\mathrm{CO}_{2}\right)$ to the great extent and in the presence of sunlight, they exhale oxygen, this process is called as photosynthesis. On the opposite of photosynthesis process at night $F$. religiosa tree uptake oxygen and discharge carbon dioxide. Some plants inhale $\mathrm{CO}_{2}$ during the night as compare to day in light, because of their capacity to perform photosynthesis is called as Crassulacean Acid Metabolism (CAM). Peepal is a hemi-epiphyte in its local environment, for example, the seeds develop and grow as an epiphyte on different trees and afterward when the host tree dies, they build on the soil. Ficus mainly use Crassulacean Acid Metabolism (CAM) pathway for deliver carbohydrates when they live as epiphyte. But in case of soil, they change to C3 type photosynthesis (Goutam et al., 2014).

\subsection{Antibacterial activity}

Antibacterial action of F. religiosa against Staphylococcus aureus, Salmonella paratyphi, Shigella dysenteriae, S. typhimurium, Pseudomonas aeruginosa, Bacillus subtilis, S. aureus, Escherichia coli, S. typhi are indicated by using aqueous and ethanolic extract.
(Mousa et al., 1994 ; Valsaraj et al., 1997; Farrukh and Iqbal, 2003). Ethanolic extract of leaves is also used in antifungal impact against Candida albicans. (Farrukh and Iqbal, 2003). For the antibacterial and antifungal activity, aqueous, methanol and chloroform extract of leaves of $F$. religiosa is used. Chloroform extract inhibit the wide range of bacterial movement, i.e., 10-21 mm. the extract of F. religiosa inhibit the vast majority of microorganisms (Farrukh and Iqbal, 2003; Hemaiswarya et al., 2009).

\subsection{Anthelmintic activity}

Methanolic extract of $F$. religious bark was active against Haemonchus contortus worms (Kaushik et al., 1981). Latex of some Ficus species, i.e., Ficus inspida, F. carica is active against parasitic infection, so it is reported for anthelmintic activity against some parasites like, Syphacia obvelata, Aspiculuris tetraptera, and Vampirolepis nana (De Amorin et al., 1999). Due to proteolytic division of Ficus, i.e., known as ficin (Hansson et al., 1986).

\subsection{Immunomodulatory activity}

Alcoholic extract of $F$. religiosa bark show the immunodulatory 
activity in mice and investigation was completed by different hematological and serological tests. Extract improve the cell and humoral counter acting agent reaction (Malluvar et al., 2008).

\subsection{Antioxidant activity}

F. religiosa extract in different sundry solvents produce the antiinflammatory activity (Bushra and Muhraf, 2009). The common endpoints of chronic infections are oxidative pressure and oxidative harm to tissues, for example, diabetes, atherosclerosis, and rheumatoid joint inflammation (Kuntal et al., 2019).

When the antioxidant status is decreases then the oxidative pressure in diabetes exists, which can increase the harmful effects of free radicals. Oxidative stress is decreases by using $F$. religiosa extract in water which help to induce experimentally type 2 diabetes in rats and improves the body weight of diabetic rats (You and Nicklas, 2006). The CAT and GSH-Px activity is controlled by the aqueous extract of $F$. religiosa bark (Kirana et al., 2009).

Methanolic extract of leaf of $F$. religiosa inhibits the nitric oxide and proinflammatory cytokines formation of in lipopolysaccharide (LPS) stimulated microglia through the pathway of mitogen activation protein kinase (MAPK) by using cell viability assay, nitric oxide test, and enzyme-linked immunosorbent assay (ELISA) (Hyo et al., 2008). Recently, neurotropic impacts and acetyl cholinesterase inhibitory action has been produced by the methanolic extract of F. religiosa (Vinutha et al., 2007).

\subsection{Wound-healing activity}

Hydro-alcoholic extract of $F$. religiosa leaves are shown wound healing property on rats using different wound models. An emulsifying ointment is formulated in $5 \%$ and $10 \%$ concentration and apply in different types of wounds and that shown fast result on wound rupturing. The topical use of leaf extract of $F$. religiosa shown dose-dependent wound healing activity (Naira et al., 2009).

\subsection{Anticonvulsant activity}

The Figs of $F$. religiosa in methanol have anticonvulsant activity without neurotoxicity in dose dependent manner such as, in picrotoxin induced convulsion and most extreme electroshock. This action was analyzed at $100 \mathrm{mg} / \mathrm{kg}$ as compare to phenytoin (Damanpreet and Rajesh, 2009).

\subsection{Hypolipidemic activity}

The dietary fiber substance affects the lipids, cholesterol, triglycerides and phospholipids of the liver to different extents. A significant relationship between liver cholesterol and serum shown by the dietary hemicellulose and also show the positive connection with fecal bile acids. Dietary fibers substance show the $10 \%$ nourishment dietary level in rats and induced more resistance from hyperlipidemia than cellulose (Agarwal and Chauhan, 1988).

\subsection{Hypoglycemic activity}

This activity is shown by the root and bark parts of $F$. religiosa from which $\beta$-sitosterol-d-glycoside was isolated (Ambike and Rao, 1967). To STZ (streptozotocin) diabetic rats, 25,50 and $100 \mathrm{mg} / \mathrm{kg}$ dose given orally. A significant reduction in blood glucose level in rats shown by using bark extract of $F$. religiosa and the effect is increasingly articulated in 50 and $100 \mathrm{mg} / \mathrm{kg}$ than $25 \mathrm{mg} / \mathrm{kg}$. It is also demonstrated that this show a critical antilipid per oxidative in pancreas of diabetic rat. This results show that bark aqueous extract has antidiabetic activity (Panit et al., 2010).

\subsection{Anti-inflammatory activity}

The effect of $F$. religiosa leaf extract in methanol is shown in lipopolysaccharide-prompted creation of NO and pro-inflammatory cytokines. A result is found in research on Ficus, the methanolic extract is active in case of tumor putrefaction factor-alpha, interleukin beta (IL) and IL-6 in BV-2 microglial cells. The methanol extract of leaf inhibit LPS-induced production of NO and proinflammatory cytokines in a dose-dependent manner.

The methanolic concentrate of stem bark has indicated antiinflammatory activity orally. In the models of acute and chronic inflammation, significant ant-inflammatory effect has been observed; the extract has also protected the mast cells from the degradation formed by various DE granulators (Vishwanthan et al., 1990) for the treatment of inflammation and burns the paste of powdered bark is used which have good absorbent property (Joy et al., 1998; Madhav et al., 2008).

\subsection{Anti-diabetic activity}

In glucose-loaded hyperglycemic and streptozotocin-induced diabetic rats, the blood glucose level is shown by using 50 and 100 $\mathrm{mg} / \mathrm{kg}$ dose. Later on, the reported results were compared with glibenclamide. The levels of serum, insulin, body weight, glycogen significantly rose up by the aqueous extract of $F$. religiosa in the liver and skeletal muscle of STZ induced diabetic rats, (Pandit et al., 2010).

\subsection{Antifungal activity}

Antifungal activity of $F$. religiosa against some microorganisms like Staphylococcus aureus, E scherichia coli, Penicillium gluacum, and Paramecium are shown by the benzene extract at a concentration of $0.2 \%$ for aqueous bark extract and for isolated compounds (Akhtar et al., 2000).

\subsection{Antiulcer activity}

In case of cold limited pressure induced gastric ulcer, and pylorus ligation, the ethanolic extract of stem bark of $F$. religiosa is used. The chances ulcer is decreased by the ethanolic extract of $F$. religiosa because Ficus increased the gastric acid $\mathrm{pH}$ as well as decreased the total acidities and also decrease the volume of gastric juice (Swami and Bisht, 1996).

\subsection{Bronchospasm activity}

Methanolic extract of $F$. religiosa does show any significant effect on the potential to create histamine-induced pre-convulsive dyspnea. In isolated guinea pig's tracheal chain and ileum preparation the methanolic extract of $F$. religiosa potentiated, the EC doses of both histamine and acetylcholine. High amount of serotonin is demonstrated in HPLC analysis of methanolic extract (Malluwar and Pathak, 2008).

\subsection{Proteolytic activity}

Latex of some species of Ficus (near about 46) is used in case of proteolytic activity and, i.e., examine by electrophoretic and 
chromatographic properties of the protein components, and $F$. religiosa has demonstrated a critical proteolytic activity (Ahuja et al., 2011).

\subsection{Anti-acetyl cholinesterase activity}

For inhibition of acetyl cholinesterase enzyme methanolic concentrate of stem bark of $F$. religiosa is used, and help to get the half-life of acetylcholine is prolonged. In Alzheimer's infections treatment, cholinesterase inhibitors are used, i.e., determine the individually half inhibitory dose was found to be $73.69 \mu \mathrm{g} / \mathrm{ml}$. The result justify the use of $F$. religiosa for the treatment of Alzheimer's disease (William, 1968).

\subsection{Anti-amnesia activity}

Anti-amnesia action was carried out using the methanol extraction of Figs on the scopolamine-induced anterograde and retrograde amnesia in mice and figs of $F$. religiosa contain high serotonergic substance. In pathogenesis of amnesia, modulation of serotonergic neurotransmission play very important role.

\subsection{Antimicrobial activity}

Antimicrobial study of $F$. religiosa is done by using different solvent like methanol, ethanol, water, acetone, etc. There are different studies carried out to detect the action of $F$. religiosa against microbes such as E. coli, A.niger, $P$. vulgaris, etc., and some antimicrobial studies of $F$. religiosa are describe in Table 2:

Table 2: Different studies for antimicrobial activity in recent years on F. religiosa

\begin{tabular}{|c|c|c|c|c|}
\hline \begin{tabular}{|l|l|} 
Part of \\
F. religiosa \\
\end{tabular} & \begin{tabular}{|l|l} 
Solvent for \\
extraction
\end{tabular} & \begin{tabular}{|l} 
Method of \\
extraction
\end{tabular} & \begin{tabular}{|l|} 
Active strains for \\
antimicrobial test
\end{tabular} & Reference \\
\hline Bark and Leaves & $\begin{array}{l}\text { Methanol } \\
\text { diethyl ether }\end{array}$ & Disk diffusion & $\begin{array}{l}\text { E.coli, P.aeroginosa, S.aureus, A.niger } \\
\text { E.coli, P.aeroginosa, S.aureus, }\end{array}$ & Ramakrishnaiah et al., 2013 \\
\hline Leaves & Water and ethanol & Disk diffusion & E.coli, P.vulgaris & Tambekar et al., 2003 \\
\hline Bark & $\begin{array}{l}\text { Acetone } \\
\text { methanol }\end{array}$ & Disk diffusion & $\begin{array}{l}\text { B.subtilis, E.coli. } \\
\text { B.subtilis, E.coli, P.vulgaris, S.aureus }\end{array}$ & Manimozhi et al., 2012 \\
\hline $\begin{array}{l}\text { Bark, Fruit, } \\
\text { Leaves, Stem }\end{array}$ & Water & Disk diffusion & $\begin{array}{l}\text { S.aureus, S.pyogens, E.coli, A.hydophila, } \\
\text { E.aerogens, P.aeroginosa }\end{array}$ & Rajiv and Siraj, 2012 \\
\hline Leaves & $\begin{array}{l}\text { Water, ethanol, } \\
\text { methanol }\end{array}$ & Disk diffusion & P.aeroginosa, B.subtilis, E.coli S.typhi & Preethi et al., 2010 \\
\hline Bark & $70 \%$ ethanol & Pylori agar plates & H. pylori & Zaidi et al., 2002 \\
\hline Bark & $\begin{array}{l}\text { Methanol, water, } \\
\text { chloroform }\end{array}$ & Disk diffusion & Three enteroxigenic, E.coli & Uma et al., 2009 \\
\hline \multirow[t]{2}{*}{ Leaves } & & Well diffusion & $\begin{array}{l}\text { S.typhi, S.typhimurium, P.vulgaris, K.pnemoniae, } \\
\text { P.aeroginosa, A.niger, P.chrysogenum }\end{array}$ & Hemaiswarya et al., 2009 \\
\hline & $\begin{array}{l}\text { Methanol } \\
\text { Water }\end{array}$ & & $\begin{array}{l}\text { S.typhi, P.aeroginosa, K.pnemoniae, } \\
\text { P.vulgaris, A.niger, P.chrysogenum } \\
\text { S.typhi, A.niger, P.chrysogenum }\end{array}$ & \\
\hline Leaves & $70 \%$ ethanol & Well diffusion & $\begin{array}{l}\text { S.aureus, E.coli, S.paratyphii, S.typhimurium, } \\
\text { S.dysenteriae, P.aeroginosa }\end{array}$ & Aqil and Ahmad, 2007 \\
\hline Bark & $\begin{array}{l}\text { Water } \\
\text { Ethanol }\end{array}$ & $\begin{array}{l}\text { Disc diffusion } \\
\text { Well diffusion }\end{array}$ & $\begin{array}{l}\text { B. cereus } \\
\text { B.cereus, P.mirabilis, S.aureus, A.foecalis, } \\
\text { S.typhimurium }\end{array}$ & Nair and Chanda, 2007 \\
\hline
\end{tabular}

\section{Results}

\subsection{Nutritional composition of $F$. religiosa}

All parts of $F$. religiosa are balanced according to their nutritional composition. In fresh fruits, $62.4 \mathrm{~g} / 100 \mathrm{~g}$ of moisture content and these are rich source of macro and micro nutrients. Carbohydrate content in fresh fruits $21.2 \mathrm{~g} / 100 \mathrm{~g}$ and crude fiber $9.9 \mathrm{~g} / 100 \mathrm{~g}$ and fresh fruit reported as a good source of carbohydrates. The quantity of protein $(2.5 \mathrm{~g} / 100 \mathrm{~g})$, fats $(1.7 \mathrm{~g} / 100 \mathrm{~g})$, ash content $2.3 \mathrm{~g}$, moisture content $62.4 \mathrm{~g}$ and calcium $(289 \mathrm{mg} / 100 \mathrm{~g})$ is present in fresh fruit (Bhogaonkar et al., 2014). In dried fruits of $F$. religiosa the net quantity of moisture content of $18.8 \mathrm{~g} / 100 \mathrm{~g}$, ash content of $4.44 \mathrm{~g} /$ $100 \mathrm{~g}$, fats $0.143 \mathrm{~g}$, carbohydrates approximately $68.33 \mathrm{~g} / 100 \mathrm{~g}$ and protein $8.48 \mathrm{~g} / 100 \mathrm{~g}$ on drying. Dietary fiber, calcium and iron has reported $69.43 \mathrm{~g}, 848 \mathrm{mg}$ and $6 \mathrm{mg} / 100 \mathrm{~g}$, respectively in dried fruit (Verma and Gupta, 2015).
Leaves and bark of F. religiosa are also used for their medicinal purpose and treat various diseases (Ruby et al., 2000). Moisture content, carbohydrates, proteins in leaves are $50.50 \mathrm{~g}, 19.20 \mathrm{~g} / 100$ $\mathrm{g}, 13.55 \mathrm{~g} / 100 \mathrm{~g}$ and fats is $2.5 \mathrm{~g} / 100 \mathrm{~g}$ (Wangkheirakpam and Laitonjam, 2012). According to report bark contain more moisture content as compare to leaves, i.e., $62.4 \mathrm{~g} / 100 \mathrm{~g}$. But, the carbohydrate and protein content of bark are less than leaves, i.e., $15.4 \mathrm{~g} / 100 \mathrm{~g}$, $2.5 \mathrm{~g} / 100 \mathrm{~g}$, respectively. Bark of $F$. religiosa is rich source of minerals and iron so that contain high mineral content of $13.1 \mathrm{~g} / 100$ $\mathrm{g}$ and iron content is $623 \mathrm{mg} / 100 \mathrm{~g}$ (Singh et al., 2015).

\subsection{Ayurvedic formulations of $F$. religiosa}

In Ayurvedic therapeutic system for the treatment of some diseases, $F$. religios $a$ is used as herbal drug. Plant parts of $F$. religiosa used in the form of oil, capsule, tablet, ointment or in crude form. Each 
formulation has own capacity to treat a particular disease. F. religiosa also consume in the form of powder being expanded in the powder structure by drying it and crush in grinders. Powder of $F$. religiosa is also used for treating certain conditions like diabetes mellitus (DM), urinary issue and so on. In the powder form of stem bark of F. religiosa give effectiveness in treatment of different diseases, if taken with honey (Singh et al., 2018). There are different formulations for different sickness, i.e., given in Table 3:

3.3 Mode of action of phytochemicals activity of plants

There are different active constituents are present in F. religiosa plant with their different activity and mechanism of action on body. The phytochemicals in F. religiosa act in different ways on different diseases, i.e., shown in Table 4:

Table 3: Some Ayurvedic formulations of F. religiosa

\begin{tabular}{|c|c|c|}
\hline Name/product & Used in disease & References \\
\hline Hand sanitizer and soap & Antimicrobial, acne, eczema, & (Afsar and Khanam, 2016) \\
\hline F. religiosa sucrose pills/urenus & Diabetes & $\begin{array}{l}\text { https://www.amazon.com/FICUS-RELIGIOSA- } \\
\text { Homeopathic-Remedy }\end{array}$ \\
\hline F. religiosa palletes/urenus & Diabetes & $\begin{array}{l}\text { https://www.amazon.com/FICUS-RELIGIOSA- } \\
\text { Homeopathic-Remedy }\end{array}$ \\
\hline $\begin{array}{l}\text { Sarivadyasava/Kerala Ayurveda Saribadyasavam, } \\
\text { Kottakkal Saribadyasavam }\end{array}$ & $\begin{array}{l}\text { Urinary diseases, } \\
\text { renal diseases }\end{array}$ & https://www.bimbima.com \\
\hline $\begin{array}{l}\text { Panchavalkadi Tailam/Ayurvedic skin care oil } \\
\text { (Arya Vaidya Pharmacy) }\end{array}$ & $\begin{array}{l}\text { Dermatitis, eczema, herpes } \\
\text { and skin conditions with bleeding }\end{array}$ & https://ayurmedinfo.com \\
\hline
\end{tabular}

Table 4: Mode of action and activity of active constituents

\begin{tabular}{|c|c|c|c|}
\hline Phytochemicals & Activity & Mechanism of action & References \\
\hline Quinones & Antimicrobial & Inactivates enzymes & $\begin{array}{l}\text { Sahoo and Nayak, } \\
2012\end{array}$ \\
\hline Flavonoids & $\begin{array}{l}\text { Antimicrobial } \\
\text { Anti diarrhoeal }\end{array}$ & $\begin{array}{l}\text { Complex with cell wall, binds to adhesions Inhibit the release of autacoids } \\
\text { and prostaglandins } \\
\text { Normalization of the DE arranged water transport across the mucosal cells, } \\
\text { Inhibits GI of acetylcholine }\end{array}$ & \\
\hline \multirow[t]{3}{*}{$\begin{array}{l}\text { Polyphenols and } \\
\text { Tannins }\end{array}$} & Antimicrobial & $\begin{array}{l}\text { Binds to adhesions, substrate deprivation, enzyme inhibition, complex with } \\
\text { cell wall, membrane disruption, metal ion complexion }\end{array}$ & \\
\hline & Anti diarrhoeal & $\begin{array}{l}\text { Metals intestinal mucosa more resistant and reduces secretion, suppression } \\
\text { of heat labile enterotoxin-induced diarrhea, astringent action. }\end{array}$ & \\
\hline & Anthelmintic & $\begin{array}{l}\text { Increases supply of digestive protein of animals by forming protein } \\
\text { complexes in rumens, interferes with energy generation by uncoupling } \\
\text { oxidative phosphorylation, causing a decrease in GI metabolism. }\end{array}$ & \\
\hline Caumarin & Antiviral & Interaction with eukaryotes DNA & \\
\hline \multirow[t]{2}{*}{$\begin{array}{l}\text { Terpenoids and } \\
\text { essential oil }\end{array}$} & Antimicrobial & Membrane disruption & $\begin{array}{l}\text { Sahoo and Nayak, } \\
2012\end{array}$ \\
\hline & Anti diarrhoeal & Inhibits release of autacoid's and prostaglandins & \\
\hline Alkaloids & Anthelmintic & Paralysis & \\
\hline $\begin{array}{l}\text { Lectins and } \\
\text { polypeptides }\end{array}$ & Antiviral & Blocks the viral infections & \\
\hline Glycosides & Anti diarrhoeal & Inhibits release of autocoids and prostaglandins & \\
\hline Saponin & $\begin{array}{l}\text { Anti diarrhoeal } \\
\text { Anticancer } \\
\text { Anthelmintic }\end{array}$ & $\begin{array}{l}\text { Increase histamine release Possesses membrane permealizing properties leads } \\
\text { to vacuolization }\end{array}$ & \\
\hline Steroids & Anti diarrhoeal & Enhance intestinal absorption of NA and water & \\
\hline
\end{tabular}




\section{Discussion}

Nanotechnology plays an important role in the field of pharmaceutical science and drug development and use of nanotechnology increases day by day. Nanotechnology is concerned with the production, manipulation and use of materials in the range of nanometer and mainly with the nanoparticles having size range is $1-100 \mathrm{~nm}$ and due to its size they are differ from the bulk material (Kavitha et al., 2013).

Nanotechnology plays an important role in human's life in all spheres (Jannathul et al., 2012). Nanoparticles mainly concerned with medicinal chemistry, atomic physics, and all other known field. Richard Feynman was the first person who give the idea about nanotechnology in 1959 and later on there are many foundations inspired by the concept of nanotechnology. In nanotechnology, synthesis and development of nanomaterials are involved.

Recently, different metallic nanomaterials are produced by using silver, copper, zinc, titanium, magnesium, gold, and alginate. For different purposes, nanoparticles are used in different sectors like in medical treatment, industry production such as solar and oxide fuel batteries, cosmetic and cloths, etc. (Dubchuk et al., 2010). Nanoparticle are classified in different types like carbon-based NP, metal NP, ceramic NP, semiconductor NP, polymeric NP and lipidbased NP. There are some formulations of leaf extract of $F$. religiosa are shown in Table 5:

Table 5: Nanoparticles of $F$. religiosa for different disease

\begin{tabular}{|l|l|l|l|}
\hline Plant part & Activity & Nanoparticles & References \\
\hline Leaf extract & Antiulcer, antidiabetic & Silver nanoparticles & Abdul et al., 2018 \\
Leaf extract & Anticancer & Copper oxide nanoparticles & Shankar et al., 2014 \\
Leaf extract & & Zinc oxide nanoparticles & Arvind et al., 2017 \\
Leaf extract & Antitumor & Silver nanoparticles & Antony et al., 2013 \\
Leaf extract & Antibacterial & Green synthesized nanoparticles & Nakkala et al., 2017 \\
Leaf extract & Wound healing & Green synthesized copper oxide nanoparticles & Shankar et al., 2015 \\
\hline
\end{tabular}

\section{Conclusion}

Medicinal plants are the local heritage with the worldwide significance. F. religiosa is a rich source of supplements just as phytochemicals. It has been utilized generally to treat numerous illnesses and is also a significant element of Ayurveda herbs. In future, F. religiosa may use in nutraceuticals and food preparation because it can fulfill the demand of nourishment and food sources. The present article shades lights on $F$. religiosa contains a few phytoconstituents like $\beta$-sitosteryl-D-glucoside, nutrient $\mathrm{K}$, noctacosanol, kaempeferol, and myricetin and nanotechnology of F. religiosa for treating different diseases and also on the different pharmacological activities like antibacterial, antifungal, anticonvulsant, immunomodulatory, antioxidant, hypoglycemic, hypolipidemic, anthelmintic, and wound healing. Nanoparticles helps to enhance the activity of $F$. religiosa and also the pharmacodynamics and pharmacokinetic property of $F$. religiosa.

\section{Acknowledgements}

The authors thank the M M College of Pharmacy Maharishi Markandeshwar (Deemed to be University), Mullana, Ambala133207, Haryana for providing the facilities and encouragement.

\section{Conflict of interest}

The authors declare that there are no conflicts of interest in the course of conducting the research. All the authors had final decision regarding the manuscript and decision to submit the findings for publication.

\section{References}

Afsar, Z and Khanam, S. (2016). Formulation and evaluation of poly herbal soap and hand sanitizer. IRJP, 7(8):54-57.

Agarwal, V. and Chauhan, B.M. (1988). A study on composition and hypolipidemic effect of dietary fibre from some plant foods. Plant Foods Hum. Nutr., 38:189-97.
Ahuja, D.; Bijjem, K.R.V. and Kalia, A.N. (2011). Bronchospasm potentiating the eect of methanolic extract of $F$. religiosa fruits in guinea pigs. J. Ethnopharmacol., 133(2):324-328.

Aiyegoro, O. and Okoh, A.I. (2009). Use of bioactive plant products in combination with standard antibiotics: Implications in antimicrobial chemotherapy. J. Med. Plants, 3:1147-1152.

Akhtar, M.S.; Iqbal, Z; Khan, M.N. and Lateef, M. (2000). Antihelmintic activity of medicinal plants with particular reference to their use in animals in the Indo-Pakistan subcontinent. Small Ruminant Research, 38:99-107.

Ambike, S. and Rao, M. (1967). Studies on a phytosterolin from the bark of Ficus religiosa. Indian J. Pharm., 29:91-94.

Antony, J.J.; Sithika, M.A.; Joseph, T.A.; Suriyakalaa, U.; Sankarganesh, A.; Siva, D.; Kalaiselvi, S. and Achiraman, S. (2013). In vivo antitumor activity of biosynthesized silver nanoparticles using Ficus religiosa L. as a nanofactory in DAL induced mice model. Colloids and surfaces. B. Biointerfaces, 108:185-190.

Aqil, F. and Ahmad, I. (2007). Antibacterial properties of traditionally used Indian medicinal plants. Methods Find Exp. Clin. Pharmacol., 29:79-92.

Asolakar, V.L.; Kakkar, K.K. and Chakre, J.O. (1992). Glossary of IndianMedical plants with active principles. Publication and Information directorate, C.S.I.R., New Delhi, pp:312-313.

Barnes, J. (2002). An introduction to herbal medicine products. The Pharmaceutical Journal, 268:304-306.

Behari, M.; Rani, K.; Usha, M.T. and Shimiazu, N. (1984). Phytochemistry and pharmacological properties of ficus religiosa: An overview. Curr. Agri., 8:73.

Bhogaonkar, P.Y.; Chavhan, V.N. and Kanerkar, U.R. (2014). Nutritional potential of Ficus recemosa Linn fruits. Biosci. Discov., 5(2):150-153. 
Bushra, S. and Farooq, A. (2008). Flavonols (Kaempeferol, quercetin, myricetin) contents of selected fruits, vegetables and medical plants. Food Chemistry, 108(3):879-884.

Bushra, S. and Muhraf, F.A. (2009). Effect of extraction solvent/technique on the antioxidant activity of selected medicinal plant extracts. Molecules, 14:2168-2180.

Chopra, R.N. and Chopra, S. (1958). Indigenous Drugs of India. 2nd ed. Calcutta, Dhur. and Sons, pp:606.

Damanpreet, S. and Rajesh, K.G. (2009). Anticonvulsant effect of $F$. religiosa Role of serotonergic pathways. J. Ethnopharmacol., 123:330-334.

DeAmorin, A.; Borba, H.R.; Caruta, J.P.; Lopes, D. and Kaplan, M.A. (1999). Anthelmintic activity of the latex of Ficus species. J. Ethnopharmacol., 64:255-258.

Dubchak, S.; Ogar, A.; Mietelski, J.W.; and Turnau, K. (2010). Influence of silver and tianium nanoparticles on arbuscular mycorhiza colonization and acumulation of radiocaesium in Helianthus anus. Span. J. Agric. Res., 8(1):103-108.

Farrukh, A. and Iqbal, A. (2003). Broad-spectrum antibacterial and antifungal properties of certain traditionally used Indian medicinal plant. World J. Microbiol. Biotechnol., 19:653-657.

Foye, W.O.; Lemke, T.L. and Williams, D.A. (2008). Foye's principle of Medicinal Chemistry, Lippincott Williams and Wilkins, 44(6).

Gautam, S.; Meshram, A.; Bhagyawant, S.S. and Srivastava, N. (2014). F. religiosa: Potential role in pharmaceuticals. Int. J. of Pharm. Sci. and Res. 5(5):1616-1623.

Gordon, M.C. and David, J.N. (2001). Natural product drug discovery in the next millennium. Pharmaceutical Biology, 39:8-17.

Hamed, M.A. (2011). Benecial effect of $F$. religiosa on high fat-induced hypercholesterolemia in rats. Food Chem., 129:162-170.

Hansson, A.; Veliz, G.; Naquira, C.; Amren, M.; Arroyo, M. and Arevalo, G. (1986) Preclinical and clinical studies with latex from Ficus glabrata HBK, a traditional intestinal anthelmintic in the Amazonian area. J. Ethnopharmacol., 17:105-138.

Hemaiswarya, S.; Poonkothai, M.; Raja, R. and Anbazhagan, C. (2009) Comparative study on the antimicrobial activities of three Indian Medicinal Plants. Eg. J. of Biol., 11:52-57.

https://ayurmedinfo.com/2012/05/11/panchavalkaditailam-benefitshow-to-use-side-effects-ingredients/ 16 Jan, (2018).

https://www.amazon.com/FICUS-RELIGIOSA-Homeopathic-Remedy

https://www.bimbima.com/ayurveda/medicinal-uses-ofpeepal-tree/673/ 14 Jan, (2018)

Hyo, W.J.; Hye, Y.S.; Chau, V.; Young, H.K. and Young, K.P. (2008). Methno extract of Ficus leaf inhibits the production of nitric oxide and Proinflammatory cytokines in LPS stimulated microglia via the MAPK pathway. Phytother. Res., 22:1064-1069.

Jannathul, F.M.; Lalitha, P. and Shubashini, K.S. (2012). Novel synthesis of silver nanoparticles using leaf ethanol extract of Pisonia grandis (R. Br). Der. Pharma Chemica., 4(6):2320-2326.

Joseph, B. and Raj, S.J. (2010). Phytopharmacological and phytochemical properties of three Ficus species: An overview. Int. J. of P. and BioSc., 1(4):246-253.

Joy, P.P., Thomas, J. Mathew, S. and Skaria, B.P. (1998). Medicinal plants. Kerela Agricultural University, Kerela, India, pp:3-8.

Jung, H.W.; Son, H.Y.; Min, H.C.V.; Kim, Y.H. and Park, Y.K. (2008). Phytother Res., 22:1064-1068.

Kalpana, G. and Rishi, R.B. (2009). Ethnomedicinal knowledge and healthcare practices among the Tharus of Nwwalparasi district in central Nepal. For Ecol. Manage, 257:2066-2072.
Kaushik, R.K.; Katiyar, J.C. and Sen, A.B. (1981). A new in vitro screening technique for anthelmintic activity using Ascaridia galli as a test parasite. Indian J. Anim. Sci., 51:869-872.

Kavitha, K.S.; Syed, B.; Rakshith, D.; Kavitha, H.U.; Yashwantha,; Rao, H.C.; Harini, B. and Pand, S.S. (2013). Plants as green source towards synthesis of nanoparticles. Int. Res. J. Biol. Sci., 2(6):66-76.

Kirana, H.; Agrawal, S.S. and Srinivasan, B.P. (2009). Aqueous extract of $F$. religiosa Linn: Reduces oxidative stress in experimentally induced type 2 diabetic rats. Indian J. Exp. Biol., 47:822-826.

Kuntal, D.; Khan, S. M.; Namratha, N.; Swetha, R. and Sevgi, G (2019). Comparative phytochemical screening, elemental content and chromatographic evaluation for detection and quantification of polyphenolic compounds for strong antioxidant activity of various extracts of Abutilon indicum (Link) Sweet leaves. Ann. Phytomed., 8(1):36-44.

Loutfy, M.H.A.; Karakish, E.A.K.; Khalifa, S.F. and Mira, E.R.A. (2005). Numerical taxonomic evaluation of leaf architecture of some species of genus Ficus Linn. Inter. J. Agric. Bio., 7:352-357.

Madhav, C.K.; Sivaji, K. and Rao, K.T. (2008). Flowering plants of Chittor District, A.P. India, pp:330-333.

Mallurvar, V.R. and Pathak, A.K. (2008). Studies on immunomodulatory activity of F. religiosa. Indian J. Pharm. Educ. Res., 42(4):343-347.

Manimozhi, D.M.; Sankaranarayanan, S. and Sampathkumar, G. (2012). Phytochemical screening of three medicinally important Ficus sp. IJPRD. 4:44-51.

Mousa, O.; Vuorela. P.; Kiviranta, J.; Abdelwahab, S.; Hiltunen, R. and Vuorela H. (1994). Bioactivity of certain Egyptian Ficus species. J. Ethnopharmacol., 41:71-76.

Murugan, A.; Kumara, K. and Shanmugasundaram. (2014). Biosynthesis and characterization of silver nanoparticles using the aqueous extract of Vitex negundo linn. World J. Pharm. Pharm. Sci., 3(8):1385-1393.

Nair, R. and Chanda, S.V. (2007). Antibacterial activities of some medicinal plants against certain pathogenic bacterial strains. Indian Journal of Pharmacology, 38:142-144.

Naira, N.; Rohini, R.M.; Syed, M.B. and Amit, K.D. (2009). Wound healing activity of the hydro-alcoholic extract of $F$. religiosa leaves in rats. Internet J. Altern. Med., 6:2-7.

Nakkala. J.R.; Mata, R. and Sadras, S.R. (2017). Green synthesized nano silver: Synthesis, physicochemical profiling, antibacterial, anticancer activities and biological in vivo toxicity. journal ELSEVIER, 499:33-45. [https://doi.org/10.1016/j.jcis.2017.03.090].

Oliver. and Bever, B. (1980). Oral hypoglycaemic plants in West Africa. Journal of Ethnopharmacology, 2(2):119-127.

Panda, S.K.; Panda, N.C. and Sahue, B.K. (1976). Phytochemistry and pharmacological properties of $F$. religiosa: An overview. Indian Veterinary Journal, 60:660-664.

Panit, R.; Phadke, A. and Jagtap, A. (2010). Antidiabetic effect of $F$. religiosa extract in streptozotocin-induced diabetic rats. J. Ethnopharmacol., 128:462-466.

Preethi, R.; Devanathan, V.V. and Loganathan, M. (2010). Antimicrobial and antioxidant efficacy of some medicinal plants against food borne pathogens. Advan. Bio. Res., 4:122-125.

Rajiv, P. and Sivaraj, R. (2012). Screening for phytochemicals and antimicrobial activity of aqueous extract of Ficus religeosa Linn. International Journal of Pharmacy and Pharmaceutical Sciences, 4(5):207-209.

Ramakrishnaiah, G. and Hariprasad, T. (2013). In vitro antimicrobial activity of leaves and bark extracts of $F$. religiosa (Linn.). Indian Journal of Pharmaceutical and Biological Research, 1(1):37-42. 
Rehmaan, A. and Aadarsh, P. (2018). Characterization of silver nanoparticles biosynthesized using Ficus Religiosa plant leaf extract. Int. Res. J. of Eng. and Tech., 5:12.

Ronsted, N.; Weiblen, G.D.; Savolainen, V. and Cook, J.M. (2008). Phylogeny biogeography and ecology of Ficus section Malvanthera (Moraceae). Mol. Phylogenet. Evol., 48:12-22.

Roy, K.; Kumar, S. and Sarkar, S. (2009). Wound healing potential of leaf extracts of religiosa on wistar albino strain rats. International Journal of Pharma Tech. Research, 1:506-508.

Ruby, J.; Nathan, P.T.; Balasingh, J. and Kunz, T.H. (2000). Chemica composition of fruits and leaves eaten by short-nosed fruit bat, Cynopterus sphinx. J. Chem. Ecol., 26(12):2825-2841.

Sahoo, R. and Dr. Nayak, (2012). Antioxidant and antimicrobial efficacy of F. religiosa L. and Ficus benghalensis L. PLANT, pp:1-41.

Salem, M.Z.M.; Salem, A.Z.M.; Camacho, L.M. and Ali, H.M. (2013) Antimicrobial activities and phytochemical composition of extracts of Ficus species: An overview. African Journal of Microbiology Research, 7(33):4207-4219.

Sankar, R.; Baskaran, A.; Subramanian, S.A. and Vilwanathan, R. (2015). Inhibition of pathogenic bacterial growth on excision wound by green synthesized copper oxide nanoparticles leads to accelerated wound healing activity in Wistar Albino rats. Springer Science, 26:214, [DOI 10.1007/s10856-015-5543-y].

Shanker, R.; Maheshwari, R.; Kartik, S. and Vilwanathan, R. (2014). Anticancer activity of $F$. religiosa engineered copper oxide nanoparticles Journal ELSEVIER, 44:234-239. [http://dx.doi.org/10.1016/ j.msec. 2014.08.030].

Satyavati, G.V.; Raina, M.K. and Sharma, M. (1976). Medicinal plants of India Indian Council of Medicinal Research, New Delhi, 1:201-206.

Singh, A.; Heer K.; Sajid, M.; Mansoori, and Chamria, N. (2017). Biosynthesis and characterization of zinc oxide nanoparticle using $F$. religiosa leaves extract. World Journal of Pharmaceutical Research, 6:10.

Singh, D.; Singh, B. and Goel, R.K. (2011). Traditional uses, Phytochemistry and pharmacology of $F$. religiosa. J. Ethnopharmacol., 134:565-583.

Singh, S.; Ahmad, P.; Sarraf, D.P.; Mishra, C. and Singh, P.K. (2018). Anticonvulsant effect of aqueous extract of aerial root of $F$. religiosa in animal models. J. Drug Deliv. Ther., 8(1):13-16.

Singh, S.; Ali, G; Singh, R. and Singh, K. (2015). Standardization of bark of F. religiosa Linn. by developing different quality control parameters. Int. J. Adv. Sci. Technol., 2(1):13-20.

Sirisha, N.; Sreenivasulu, M.; Sangeeta, K. and Chetty, C.M. (2010). Antioxidant properties of Ficus species: A review. International J. Pharma Tech. Research, 3:2174-2182.
Starr, F. K. and Loope, L. (2003). F. religiosa Bo Tree Moraceae. United States Geological Survey-Biological Resources Division, http:// www.hear.org/starr/hiplants/reports/pdf/ficus_religiosa.pdf.

Swami, K.D. and Bisht, N.P.S. (1996). Constituents of F. religiosa and Ficus infectoria and their biological activity. J. Ind. Chem. Soc., 73(5):631.

Tambekar, D.H.; Tiwari, B.K.; Shirsat, S.K. and Jaitalkar, D.S. (2013). Antimicrobial Potential and Phytochemical Analysis of Medicinal Plants from Lonar Lake. IJLPBR, 2(3):203-211.

Trivedi, P.; Hinde, S. and Sharma, R.C. (1969). Preliminary phytochemical and pharmacological studies on racemosa. Journal of Medicinal Research, 56:1070-1074.

Uma, B.; Prabhakar, K. and Rajendran, S. (2009). In vitro antimicrobial activity and phytochemical analysis of F. religiosa L. and Ficus bengalensis L. against diarrhoeal enterotoxigenic E. coli. Ethnobotanical Leaflet, 13(17):472-474.

Valsaraj, R.; Pushpangadan, P.; Smitt, U.W.; Adersen, A. and Nyman, U. (1997). Antimicrobial screening of selected medicinal plants from India. J. Ethnopharmacol., 58:75-83.

Verma, I. and Gupta, R.K. (2015). Estimation of phytochemical, nutritional, antioxidant and antibacterial activity of dried fruit of sacred figs (F. religiosa) and formulation of value added product (Hard Candy). J. Pharmacogn. Phytochem., 4(3):257-267.

Verma, R.S. and Bhatia, K.S. (1986). Chromatographic study of amino acids of the leaf protein concentrates of F. religiosa and Mimusops elengi Linn. The Indian Journal of Hospital Pharmacy, 23:231-232.

Vinutha, B.; Prashanth, D. and Salma, K. (2007). Screening of selected Indian medicinal plants for acetyl cholinesterase inhibitory activity. J. Ethnopharmacol., 109:359-363.

Viswanthan, S.P.; Thirugnanasam, B.M.; Reddy, K.S.; Narasimhan, G. and Subramaniam, A. (1990). Anti-inammatory and mast cell protective eect of religiosa. Ancient Science of Life, 10:122-125.

Wangkheirakpam, S.D. and Laitonjam, W.S. (2012). Comparative study of leaves of Ficus pomifera wall, Ficus hispida Linn. and F. religiosa Linn. For the biochemical contents, minerals and trace elements. Indian J. Nat. Prod. Resour., 3(2):184-188.

William, D.C. (1968). Proteolytic activity in the genus Ficus. Plant Physiology, 43:1083-1088.

You, T. and Nicklas, B.J. (2006). Chronic inflammation: Role of adipose tissue and modulation by weight loss. Curr. Diabetes Rev., 2:29-37.

Zaidi, S.F.; Yamada K.; Kadowaki, M.; Usmanghani K. and Sugiyama, T. (2009). Bactericidal activity of medicinal plants, employed for the treatment of gastrointestinal ailments, against Helicobacter pylori. J. Ethnopharmacol, 121:286-291. 